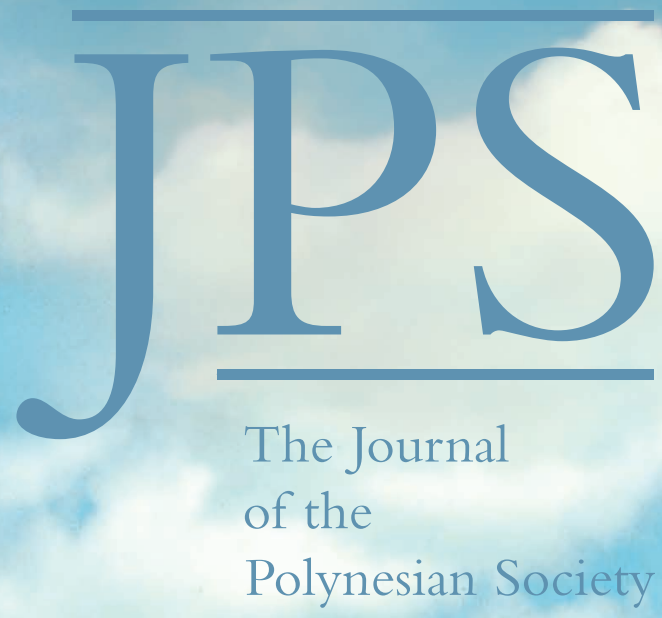

VOLUME 127 No.3 SEPTEMBER 2018

THE POLYNESIAN SOCIETY

THE UNIVERSITY OF AUCKLAND

NEW ZEALAND

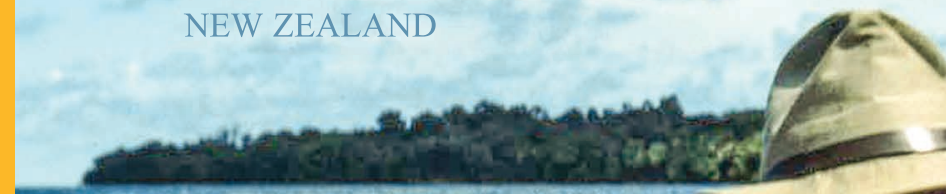

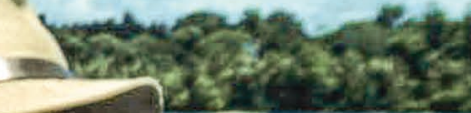

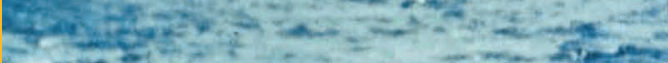

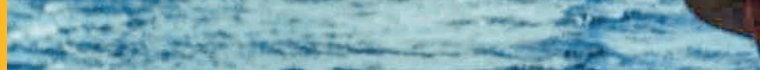

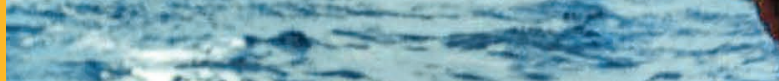

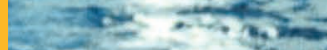

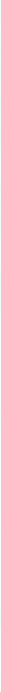




\title{
MOVING THROUGH THE ANCIENT CULTURAL LANDSCAPE OF MANGAIA (COOK ISLANDS)
}

\author{
MICHAEL P.J. REILLY \\ University of Otago
}

\begin{abstract}
The distinguished Pacific scholar and writer Epeli Hau'ofa envisions Oceania as an interconnecting world of movement between and within islands. In earlier times, Pacific peoples navigated their way on ocean-going vessels to other islands to trade, to expand "social networks", to search for adventure or to seek war and dominate other groups of Islanders (Hau'ofa 2008: 33). They also participated in a "more localised mobility" within islands where the natural landscapes of particular lands were "maps of movements, pauses, and more movements" (Hau'ofa 2008: 72-73). Island landscapes are never passive elements, but rather actively contribute to the cultural world of the people who travel about in them. In a classic definition, geographer Carl Sauer explains this dynamic connection:
\end{abstract}

The cultural landscape is fashioned from a natural landscape by a culture group. Culture is the agent, the natural area is the medium, the cultural landscape the result. ... The natural landscape is of course of fundamental importance, for it supplies the material out of which the cultural landscape is formed. The shaping force, however, lies in the culture itself. (Sauer 1963:343)

In order to move around in such a cultural landscape people need to possess some kind of "spatial consciousness" in the form of a cognitive map of their surrounding physical world (Mawyer and Feinberg 2014: 245). In finding their way through the land they also observe "the traces of other people's movements and agency", and listen to "the narratives of yet other people's agency" (Gow 1995: 59). By recounting these narratives at the places where they occurred, a new generation learns about their ancestral past: "the landscape tells - or rather is - a story. It enfolds the lives and times of predecessors who ... have moved around in it and played their part in its formation". To look at a landscape is "an act of remembrance" for "an environment that is itself pregnant with the past" (Ingold 1993: 152-53).

This paper originates in my own slow realisation that the traditions I discovered in archives and books were located within an "eco-cultural history" of particular cultural landscapes (Lepofsky et al. 2017: 459). Two quite different kinds of authorities influenced me. The first was my reading of some of the publications arising from an important interdisciplinary research project, begun in 1989, that looked at how people transformed the ecological 
systems of colonised islands, with a particular focus on Mangaia (Fig. 1). The project also drew on oral traditions and ethnohistorical sources to help explain aspects of the longer-term process of landscape and environmental change (e.g., Kirch 1994 [especially chapter 4 on Mangaia], 1996, 2017; Kirch and Hunt 1997; Kirch et al. 1991, 1995). The second influence came about when I was privileged to be taken in hand by several Mangaians, notably Teariki No 'oroa and Mataora Harry, who talked to me about their island's landscape. Mataora, late kavana 'chief' of Kei'à district, had a big hand in my education when he invited me to stay with him in $1998 .{ }^{1}$ In between discussing various traditions and their appropriate translations, Mataora began taking me on tours of the different historic sites we were talking about, bumping our way

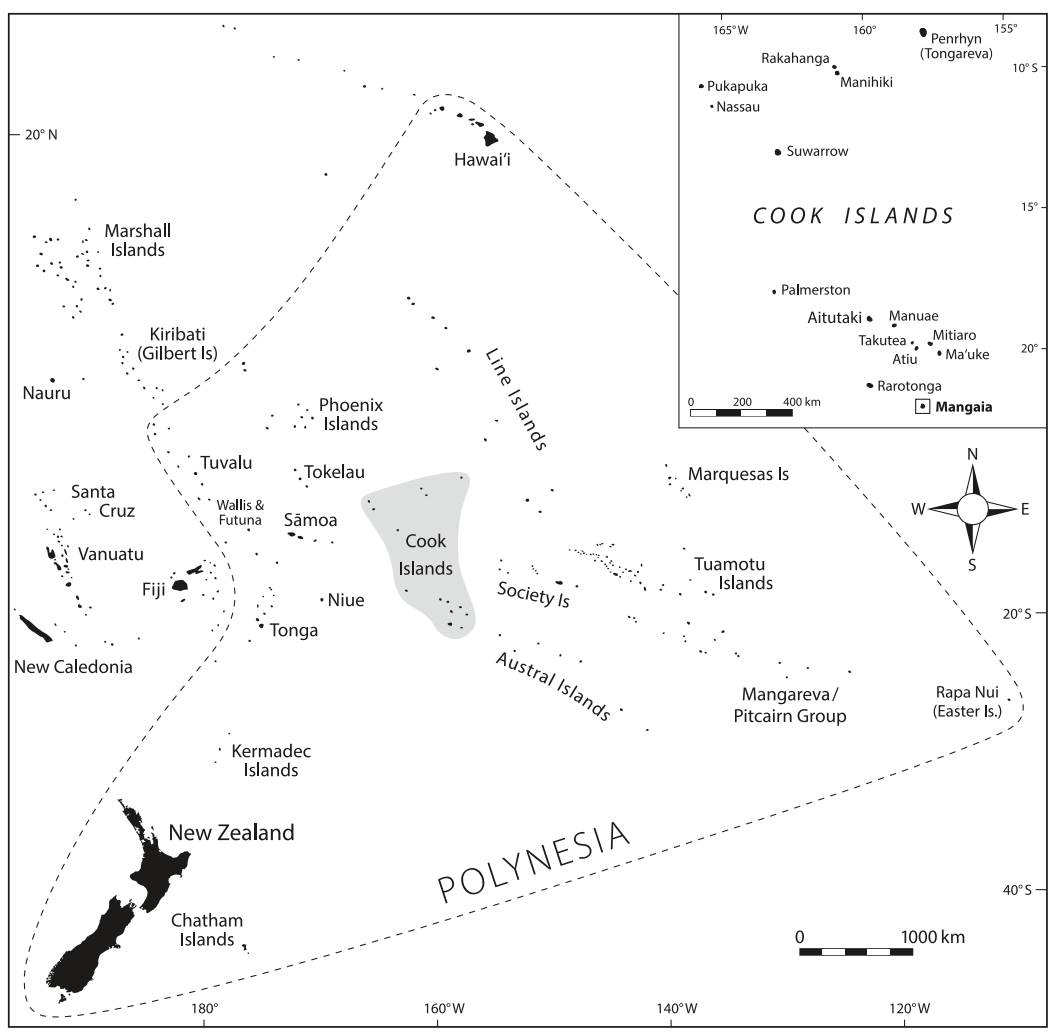

Figure 1. Mangaia in the Pacific. Map by Les O’Neill, 2017. 
in his truck along the old, inland paths that had been widened for four-wheel vehicles. He would periodically stop on high points of the island so that I could get an overview of the island's landscape. We also visited a range of historic sites: old marae 'sacred sites' hidden in the luxuriant tropical bush, such as Ōrongo, Tukitukimātā, 'Aka'oro, Rangita'ua, Maungaroa and 'Aumoana; the pool, Vairorongo; the 'are va 'ine 'women's house', Te Puaimatareka; and famous lithic landmarks, like 'Oimara's stone and Moke's footprint. One day we waded through the lagoon to an ancient battle site at a fishers' cave, Ananui, with the help of a local guide Mataora had organised.

These trips, intended as a visual complement to the discussions of vernacular written texts, resemble other journeys. In the Marquesas Islands, Emily Donaldson and locals walked up the valleys and chatted about the ancestral sites they visited. She observes that such "embodied relationships to the land" allow locals "to engage with specific features and memories of ancient sites, carving place out of space" (Donaldson 2018: 9). For Huli historians in the Southern Highlands of Papua New Guinea, oral testimony given at the right physical location combines "with the visual and sensory evidence to impress on the audience the truth of the past" (Ballard 2014: 106-7); the sites themselves become "portals to an archive of memories of movement" (pp. 97-98). The elders in the indigenous communities of coastal British Columbia prefer to talk about their knowledge of the old ways, such as fishing or harvesting, at the appropriate cultural sites where these were practised so as to ensure the younger generation learns not only how to do things correctly but where the tasks should be appropriately carried out (Lepofsky et al. 2017: 455). Just so, by taking me to specific historic places in Mangaia, Mataora made sure I understood that the words about which we were talking so abstractly were rooted deeply in particular parts of his island, a land alive with multiple layers of ancestral associations.

The stories remembering Mangaia's past stem from the extraordinary collaborations between the London Missionary Society's William Wyatt Gill, who served the people of Mangaia between 1852 and 1872, and his numerous indigenous consultants who shared with him their knowledge of their island's cultural landscape. In a series of publications Gill retold these stories, quoting songs and proverbs associated with particular ancestral deeds within their natural world. While the stories themselves are told in English they draw from the oral traditions he heard from his Mangaian associates. Low-priced republications by the University of the South Pacific ensure several of Gill's key works remain accessible to Oceanic audiences, including Mangaians, for whom these writings are "artifacts of continuing value" (Myers 2017: 9, 11), preserving and perpetuating that ancestral knowledge, as living documents, for new generations of local (and other) readers. 
In some of these stories Gill gives us a sense of how he and his local consultants went about remembering the people and places associated with them. A good example introduces the story of the war refugee, Vivi. Gill explains that one day he walked through the centre of the island, heading to the other side of it, accompanied by "an intelligent young man as a guide". His unnamed Mangaian guide suggested they leave their narrow path "in order 'to see where Vivi rolled himself down'", to which Gill agreed. He continues: "A few minutes' walk along a narrow hill-ridge through the crisp fern which we crunched under our feet, brought us to a conical eminence, up which we climbed. On either side was a deep valley with precipitous sides. ... 'Down there', said my guide, 'rolled poor Vivi'". The guide told Gill the story as the two men rested under the shade of some toa 'ironwood' (Casuarina equisetifolia) trees (Gill 1984 [1894]: 115-16).

In this account Gill shows how he learned about the island's past as he moved across the landscape, often as part of his pastoral duties. Other times, he explored some part of the landscape which Mangaians had mentioned in their narratives, always taking along local people to show him about (e.g., Gill 1984 [1894]: 214-36). As in this example, these Mangaian guides would suggest interludes in their journeys so that the party could sit and hear a story associated with the place. Gill went to great lengths to see the places and to hear the stories associated with them. He prefaces various accounts with descriptions of how he climbed trees, clambered up cliff faces, explored subterranean caves and walked through the makatea (Fig. 2) and the räei kere. The makatea is an ancient uplifted reef that surrounds the island like a fortress wall and possesses a forbidding surface of "hard, splintery limestone" with "sharp serrated pinnacles" and many crevices, covered over in "a tangle of interlacing vegetation" (Kirch 2017a: 9-12; Marshall 1927: 20). The rāei kere 'black rocks' is an area of the southern makatea characterised as a desolate moonscape devoid of any vegetation ('Aerepō n.d.a; Gill 1984 [1894]: 216-17). Such challenging locations show the extent of Gill's desire to understand fully the local world of his parishioners, a commitment that doubtless encouraged Mangaians to tell him stories about the land and its people.

The following paper is divided into three sections. In the first, the paper introduces local directions which orientate travel about the land. These come from conversations with locals, modern ethnographies and historical and contemporary language samples. In the second section, the paper focuses on what can be learned from the historical literature about the island's ara 'paths, tracks' that continue to allow people to criss-cross the land. The final part of this paper describes the kinds of journeys undertaken in ancient Mangaia, including processions for ritual or mourning, expeditions to seek victims or make war, and trips to use resources or attend entertainments. 


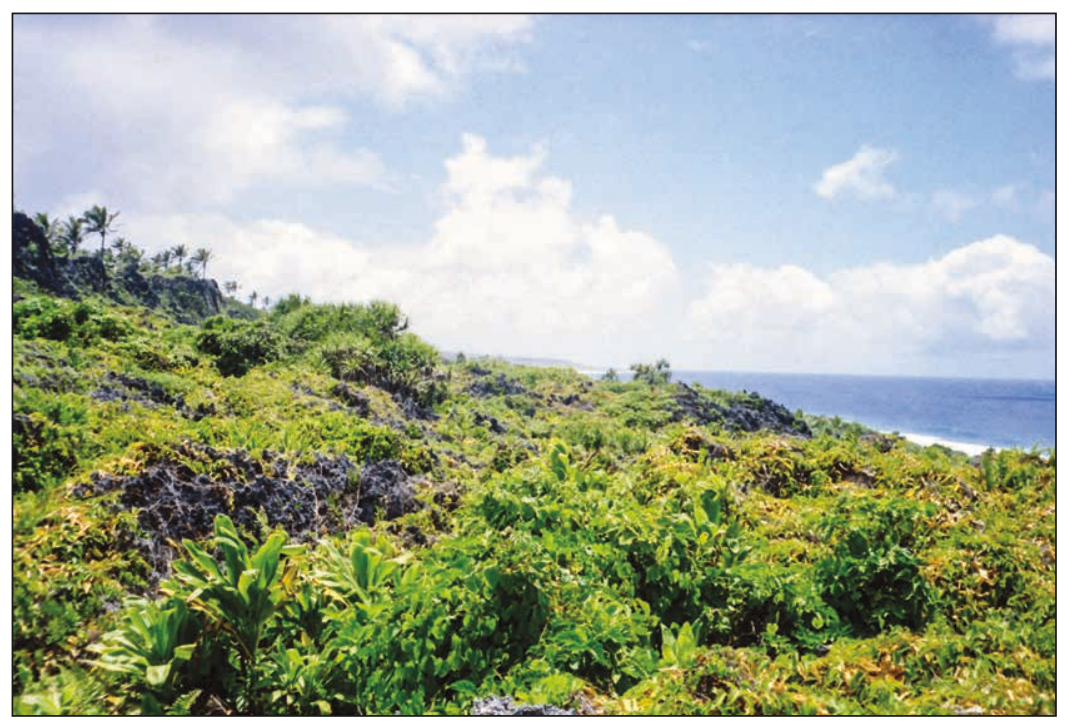

Figure 2. Makatea near coastal road, Veitātei. Author's photograph, 2001.

\section{DIRECTIONS}

In writing about spatial relationships in Tonga, Giovanni Bennardo (2014: 254) observes that "giving directions is an activity which requires the activation of deeply seated knowledge of one's environment (physical and social)". In Mangaia, people utilise a series of locative bases in order to communicate a quite precise location and directionality in terms of a subject's movements within the landscape. With reference to the culturally related society of Mangareva in French Polynesia, Alexander Mawyer, citing William Hanks, explains such locatives as "referential practice" whereby a person is able "to locate [themselves] in the world, to occupy a position, however fleetingly, in one or more sociocultural fields" (Hanks 1990: 514 quoted in Mawyer 2014: 287).

For Mangaia, the first locatives are the oppositional pair of tai 'sea, seaward' and uta 'inland, landward, ashore'. Concerning ancient Tahiti, Douglas Oliver (1974: 584) suggests this contrast "was a fundamental one to these land-dwelling but sea-going Islanders". Mawyer (2014: 288) notes similar usages throughout Polynesia, suggesting there is "a standard model of the Polynesian cultural figuration of sea-land orientation". This polarity 
is also significant in Mangaia as it appears elsewhere in the local cultural world, for example, in the titles of the two most prestigious pre-Christian priestly offices, the ariki p $\bar{a} u t a$, responsible for inland and eastern parts of the island, and the ariki pa tai, responsible for the western shore (Reilly 2009: 47). Sample historical sentences illustrate how these locatives are used. Both appear in a dream later recounted by the ariki pā uta, Nūmangātini, about his first encounter with Christian missionaries:

Té 'aere ra aia e 'ätoro i taua pa ‘̀ rā, e tae atura aia ki tai $i$ Ōrongo. Kite atura aia $i$ 'e tokorua tangata nō runga mai i te pa 'ī kua tau mai i uta $i$ Avarua.

He was walking down to the shore at Ōrongo [a marae or sacred site] to take a look at the ship. He saw two people from the ship land at Avarua (underlining added) [a reef channel; Fig. 3]. (pp. 113-14)

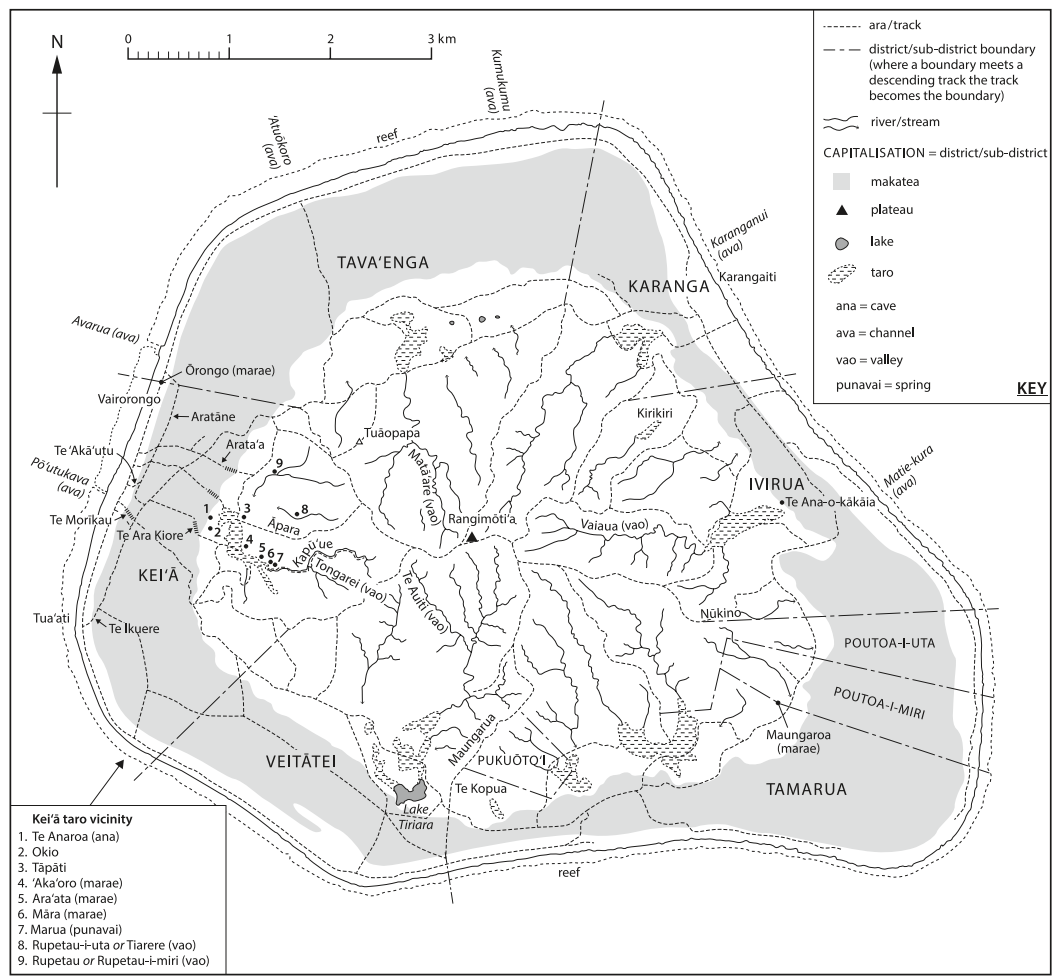

Figure 3. Mangaia's cultural landscape. Map by Les O’Neill, 2017. 
In the first sentence Nūmangātini is walking from the hinterland towards the sea. In the second, the two men from the missionary ship, described as a $\mathrm{pa}^{\prime} \mathrm{l}$, the word for Oceania's sea-going double-hulled canoes, have come ashore at the reef channel, that is, they have travelled in a landwards direction. Both locatives also appear together in an old song where defeated Teipe tribal members are described as birds flitting inland and seaward in a desperate search for a refuge from their enemies: "Nā uta, nō tai, 'akaea Teipe тапиа" (Gill 1984 [1894]: 122). At any point of a line drawn between the centre of the island, the maunga 'mountain', and the sea, a Mangaian can plot their position in relation to these two locatives. The mountain itself has been described as "the most extreme point ' $i$ uta (landward) possible", just as the sea was the extreme termination in the other direction (Mark 1976: 43 , underlining in original). ${ }^{2}$

The second contrastive locative pair comprises runga 'up, east' and raro 'down, west'. ${ }^{3}$ The anthropologist Mary V. Mark identifies two local ways of using these locatives. First, if applied vertically, runga and raro locate a person's movement up and down as they travel across the island's rugged landscape (Mark 1976: 44-45). Two samples from historical narratives illustrate this usage: "kake atura nā runga $i$ te maunga" "climbed up the mountain' (Reilly 2009: 27); "taka atura rāua i raro i têta 'i ngā ' $i$ 'aka 'aka" 'they fell down into a low area' (Reilly 2010: 130). In the last sample, two brothers fighting on a trail fell down the mountain side.

The second local use of these locatives applies them horizontally to the landscape. As Mark explains, runga and raro refer to a person who travels on a circular course around the island, keeping parallel to the sea and the mountain. A person is travelling $k i$ / ' $i$ runga when they move from Kei'a district in the west and head around the northern side of the island to Tamarua district, at the eastern extremity, before returning through the southern side back to their starting point (Fig. 3). If the traveller were to reverse the direction of their journey around the island they would be going $\mathrm{ki}$ / ' $\mathrm{i}$ raro (Mark 1976: 45-46). Put more simply, a traveller going 'i runga is heading eastwards while ' $i$ raro is going west.

This application appears in various historical and contemporary examples. Polynesian navigators referred to sailing east as runga and west as raro (Gill 1876a: 25). Oliver (1974: 584) explains this nautical usage as "upwinddownwind (i.e., toward or away from the prevailing easterly trades)", directions that would have applied as much in Mangaia as in Tahiti since both islands are roughly located on an east-west axis. Mangaian sentence samples illustrate local usages of this east-west orientation: " $E$ anga ki runga; e anga ki raro" 'Look eastward; look westward', from an 18th-century lament (Gill 1876b: 197); "Ka 'aere au i runga i Tamarua" 'I'm going up (east) to Tamarua' (Mauriaiti et al. 2006: 416). Other text samples demonstrate that 
people located in each of Mangaia's six districts generally use runga for movement in an easterly direction and raro when moving westwards within their various districts (Shibata 1999: 244). The one anomaly arises when someone positioned in Oneroa village, in the western district of Kei ${ }^{`} \bar{a}$, heads towards the southern side of the island, in the direction of Veitātei district. They are considered to be moving ki raro (Mataora Harry pers. comm., 24 January 2003; Shibata 1999: 244; Tua'ine Papatua pers. comm., 30 January 2017). My best guess is that for someone positioned on the west coast, runga is a clockwise progression by way of the northern side of the island to the east while raro is a counter-clockwise progression through the southern side of the island to the east and back round towards the west again.

Mataora Harry (pers. comm., 24 January 2003) draws on the ancient conceptualisation of Mangaia as a fish when talking about this horizontal usage of runga and raro. Someone travelling ki runga is moving in the direction of the districts considered the päuru 'head of the fish', Ivirua and Tamarua, located on the east side of the island. Conversely, someone travelling ki raro is heading from the pāuru towards the districts at the other extremity, Kei'ā and Tava'enga, on the western coast, metaphorically considered the ' $u k u$ or ' $i k u$ 'the tail of the fish' (Fig. 3). ${ }^{4}$

Another locative, roto 'inside, within', is used in relation to the makatea which measures between a half and two kilometres in width (Kirch 2017a: 10). As Mataora Harry explains it (pers. comm., 24 January 2003), if someone walks into the makatea's bush, perhaps to collect maire (Alyxia stellata), or coconut to feed their pigs, then they are said to be "tei roto i te makatea" 'in the makatea'. A historical narrative describes survivors of a massacre who ran away and " "ua no 'o $i$ roto i te makatea" 'dwelt inside the makatea' (Reilly 2009: 213). In both cases the people concerned had ventured into the inner recesses of the makatea where the bush cover would have made for an excellent refuge in pre-Christian times.

Another orientation of the Mangaian landscape is revealed by the locatives mиа 'front, before' and miri or muri 'behind, back, rear, after'. ${ }^{5}$ An old story from Mangaia describes how a challenger for the high chiefly (mangaia) title lodged faeces in an irrigation channel, "ia tere te kava o te tütae i miri" "in order to hasten the bitter taste of the faeces $i$ miri'. In English miri might be translated as downstream, referring to the water's movement through the channel towards the makatea. However, during a discussion of this incident in the story, Teariki No' oroa pointed out to me a more fundamental orientation of Mangaia's natural and cultural landscapes. As he explains it, the irrigation system begins in the mountain, the source of the fresh water that sustains the entire system of wetland taro plantations found in the valleys. ${ }^{6}$ The interior mountain is therefore the front or beginning ( The water flows through the various taro plots till reaching the back or end 
(miri) of the system, the last plots before the water disappears under the makatea and so out to sea. Teariki reminded me that in the pre-Christian era Mangaians lived in the inland areas of their districts. In that situation they conceived of their system of irrigated plantations as being orientated to face towards the mountain (Fig. 4; Reilly 2009: 181, 299 n.12).

As a directional term тиа indicates a location closer to the mountain whereas miri refers to that part of the pre-Christian interior living spaces nearest the makatea. An old story describes the ancestral founder, Rangi, travelling "nā miri ... nā te pae mato" 'behind ... by way of the cliffs', a reference to the inner-facing cliffs of the makatea (Fig. 5; Reilly 2009: 24-25). This organisation of the landscape is confirmed by past and present sub-district (tapere) names: Rupetau-i-uta and Rupetau-i-miri in Kei 'ā and Poutoa-i-uta and Poutoa-i-miri in Tamarua (Fig. 3; Hiroa 1971 [1934]: 127-28). Mataora Harry (pers. comm., 24 January 2003) confirms that the places with the suffix $u t a$ are nearer to the mountain than those with the suffix miri. In this usage, uta refers to the inland area which conceptually is considered to be mua.

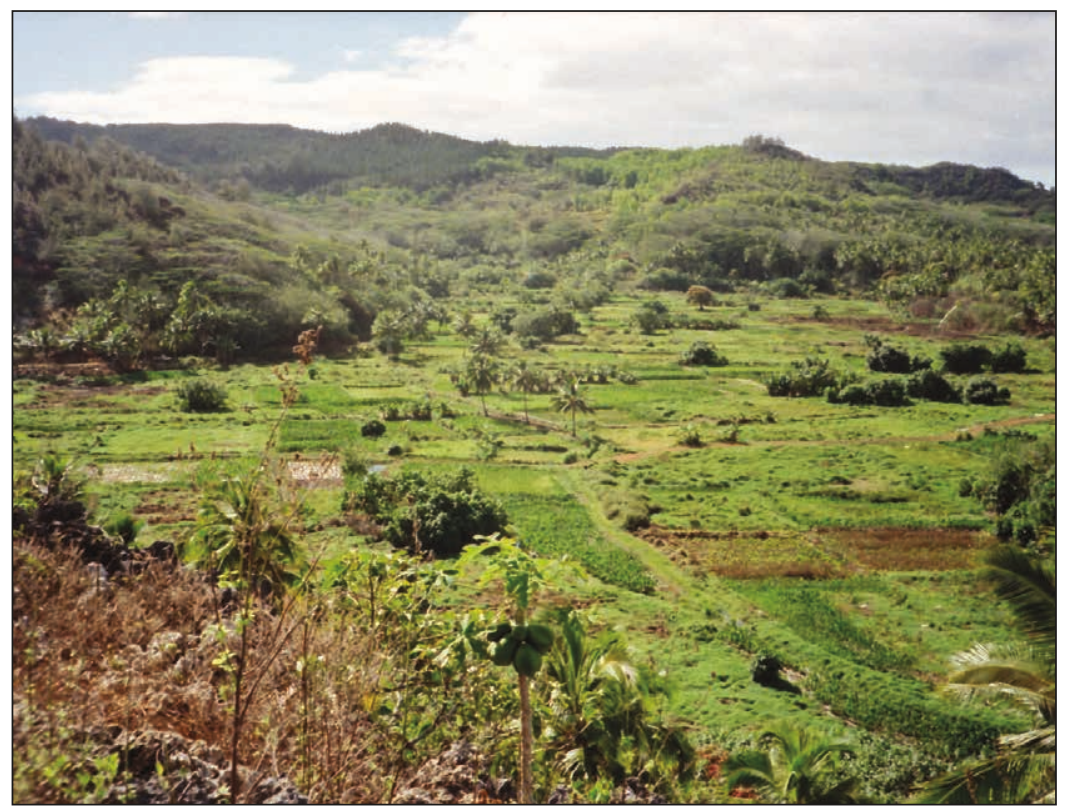

Figure 4. A view from the makatea of Tamarua's taro swamps facing the mountain in background, with paths (widened for modern vehicles) criss-crossing the valley floor. Author's photograph, 1998. 
By contrast, miri is in the direction of the tai. Hence Mangaian people had their backs to the sea and faced towards Rangimōti'a, the mountain named by the founding ancestor of Mangaian society (Mataora Harry pers. comm., 18 October 2001). As directional terms mиa and miri seem more localised forms, orientated along the uta-tai line, but focused on the relationship of the interior living and planting areas to the mountain and the makatea, both of which loom over the lands where the people dwelt in the pre-Christian era. Given that the mountain provides the people with the source of their fresh-water supply it is not too surprising that they orientate their world to look in that direction.

According to Mawyer (2014: 281), Oliver thought the mua-muri pair was culturally foundational in relation to Polynesian spatial orientation. Oliver himself speculates that mua-muri primarily referred to "socially valued activity" in ancient Tahiti, so that mua might be more accurately translated as "center, or focus (of some interest)", and muri as "margin of the same" (Oliver 1974: 1082, italics in original). Mangaian usages indicate that mua and $u t a$ refer to more socially significant and culturally valued inland spaces, in contrast to tai and miri (muri) which encompass the makatea and coast, both considered marginal living areas until the advent of Christianity.

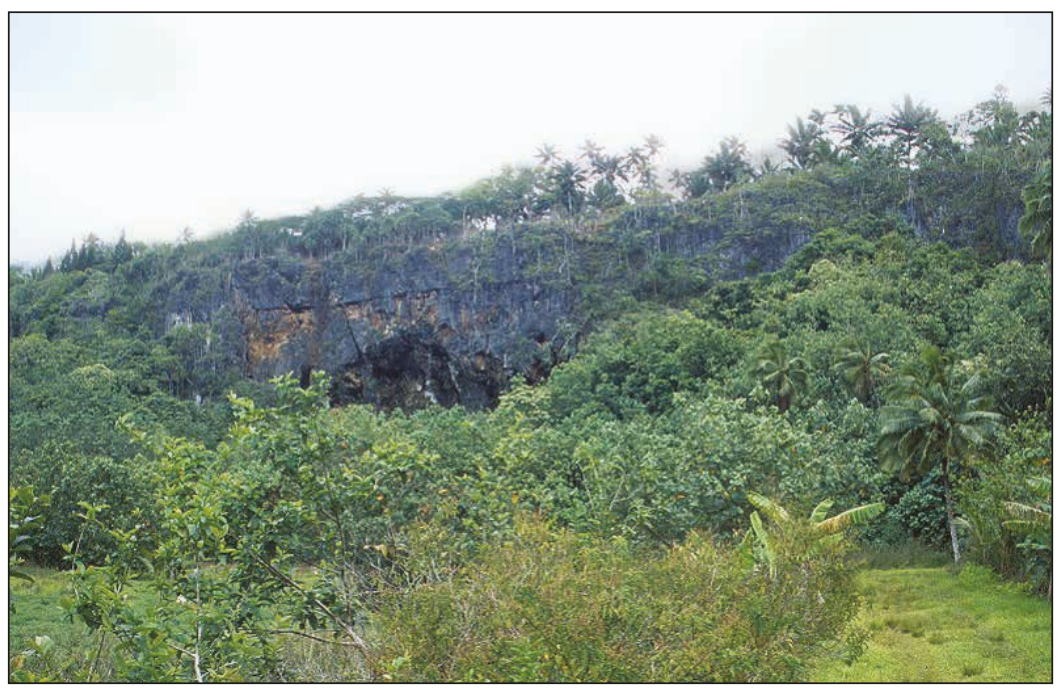

Figure 5. Kei'à's inner-facing makatea cliff with inland path (right foreground) widened for modern vehicles. Photograph by Richard Walter, 2001. 
Mangaians use locative bases to describe the particular directions they take as they journey through their island landscape. Their movements to the sea, inland towards the mountain, in an easterly direction towards the head of the fish, or into the makatea, all identify their journey in relation to an absolute position in the surrounding landscape. Travel is described as radiating out from or to some fixed and constant point in the spatial environment, a perspective Mangaians share with other Polynesians (Bennardo 2014: 257-58, 261, 266-67; Mawyer 2014: 284).

\section{PATHWAYS}

Mangaia is criss-crossed by numerous ara that help tie people together and enable access to various land and sea resources (Fig. 3). The first paths appear in the foundation stories about Mangaian society. For example, when the early Tonga 'iti people were defeated in battle in Kei'ā district the survivors fled by a road right across the island to Tamarua. Many of the places along the pathway are named after the warriors killed at these spots as they stood to fight their pursuers (Gill 1876b: 288; Reilly 2003: 28; Shibata 1999: 138, $323)$. They became part of the landscape, imbuing it with human associations that are remembered in the stories told about these locations, themselves now "the stage set for the human drama itself" (Richards 1999: 91).

Paths ran up the steep-sided mountain ridges from the interior valleys and across Rangimōti'a which seems to have served as a central junction (Fig. 3). As in Gill's day, these main trunk roads allowed people to move from one valley or district to another. Historical narratives describe these pathways as ara iti 'narrow tracks', requiring groups to pass in single file (Gill 1885: 99-101; 1984 [1894]: 193-94, 115; Shibata 1999: 138). For example, Ivirua invitees to an important feast in Kei'a proceeded down the Āpara mountain ridge to Tāpāti lying at its foot and the site of the feast (Fig. 3). An army marching to battle in Ivirua took the same route in reverse (Gill 1984 [1894]: 166-67; Hiroa 1971 [1934]: 56; Pāmetu Metuauti pers. comm., 24 October 2001; Reilly 2003: 61-62). Two Ivirua men in search of retribution took the Karangapai ridge and descended into Tamarua's Te Kōpua sub-district (Fig. 3; Aratangi n.d.a). When parties met there could be disputes, especially when persons of consequence were involved as neither wished to step aside and risk coming under the other's mana 'authority' (e.g., Gill 1876a: 353-4). However, on reaching the flat mountain summit the principal track widened out becoming an ara ngao or ara nui ätea 'wide path'. Off it ran various narrow minor pathways leading down the mountain's steep slopes to particular residential areas in the valleys below (Gill 1876a: 344-6; Shibata 1999: 34).

Other paths radiated outwards in the opposite direction, like spokes of a wheel, from the valleys down to the sea, known as ara 'aere $i$ tai 'paths going 
to sea' (Shibata 1999: 34). These paths allowed access to the coastal and sea resources for the people who, up to the Christian era, lived enclosed lives in their käinga 'living areas' in the interior valleys. Unlike the apparently anonymous ridge and mountain trails, these land-to-sea paths are identified by name. For example, the Arata'a path saw the chiefly Paoa take leave of his family and go down to Avarua, or another reef channel, and seek death at sea in consequence of a verbal attack that affected his mana (Fig. 3; Gill 1984 [1894]: 275-82). Another Kei' $\bar{a}$ path through the narrow gorge, Te Ikuere (or Te Ikuari), witnessed the killing of the chiefly woman, Tā'aumārama, returning from the reef at Tua'ati with calabashes filled with salt water for cooking - a victim of her father's political intrigues (Fig. 3). He later chose this spot to go down fighting against his opponents, joining his beloved daughter in death (Gill 1984 [1894]: 88; Reilly 2003: 50-51; 2009: 184-85; Shibata 1999: 339). In Tamarua, the important valley-to-sea track, Teone, became a critical escape route into the makatea for survivors of the battle at nearby Pukuōto'i ('Aerepō n.d.b; Gill 1984 [1894]: 170-72, 183, 196-97; Hiroa 1971 [1934]: 62). Other seaward paths include Te Morīkau in Kei' $\bar{a}$ (Fig. 3), Raurau in Veitātei, Anarea in Ivirua and Karangaiti and Arapiri in Karanga. All these paths were "narrow and rugged", but used daily by fishers and those collecting seawater for cooking (Fig. 6; see 'Aerepō n.d.c; Aratangi n.d.b; Gill 1984 [1894]: 28-31, 103-4, 110-11, 177-80; Shibata 1999: 300, 311).

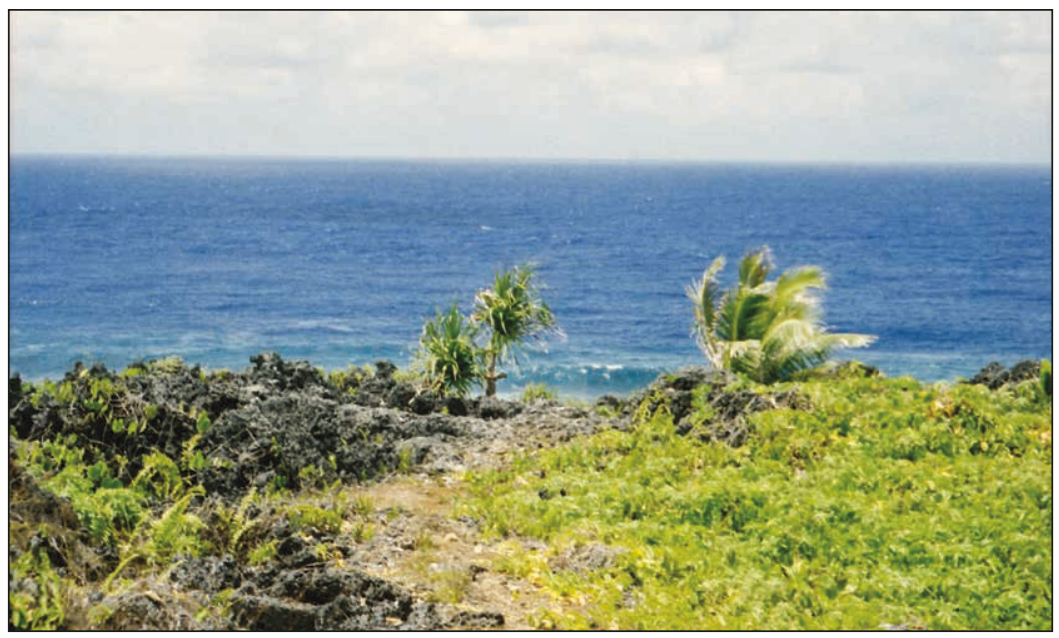

Figure 6. A path (centre) through makatea from Veitātei's coast inland to Lake Tiriara. Author's photograph, 2001. 
War refugees sheltering in the makatea used these valley-to-sea tracks as they moved in and out of their hiding places, playing an endless cat-and-mouse game with enemy warriors in search of them (Gill 1984 [1894]: 152-53). The heroine, Kārua, at great personal risk, warned her brother-in-law of an assassination plot by running in the dead of night to his residence inland along one of these paths winding through the jagged makatea, an act, Gill points out, difficult enough to do in daylight (pp. 161-62). When these paths went down the makatea cliffs they were called ara 'eke 'eke 'descending paths' (Shibata 1999: 34), and even today some require great care, comprising only a few flattish rocks placed at intervals down the cliff face.

Located between the dominating crest of the mountain and the high cliffs of the makatea, the interior living areas were criss-crossed by pathways running the length and breadth of each valley. These were the ara 'aere $i$ te käinga 'paths going to the inland living areas' and ara i uta 'inland paths' (Shibata 1999: 34). In Kei'ā, perhaps one of the best-known internal paths is Te Ara Kiore 'The Rat's Pathway', the main track connecting the valley to the top of the makatea from whence it links up with other paths either inland to Veitātei, or by way of the Aratāne path, through an area of the makatea known as 'Are-mauku, down to the sea at Avarua (Fig. 3; Gill 1984 [1894]: 292-93; Mataora Harry pers. comm., 3 July 1998; Shibata 1999: 36). At the Aratāne, atop the makatea, stood the early mangaia, Mokea, watching for any Rarotongan warriors returning in search of a compensatory victory for their earlier drubbing at the hands of Mangaia's defenders ('Aerepō n.d.d).

The various valleys in each district possessed a network of paths, including subsidiary tracks in the smaller tributary valleys and arterial roads running the length of the main living areas. These pathways formed the stage set for the two refugees, Vaiā and his sister, Mangaia, who had descended into Tongarei, a long valley in Kei'ā, where they were seized by nearby residents and taken by a narrow path to the ara nui 'main road' at Kapu' 'ue, site of a waterfall and pond (Fig. 3). Here they were met by Te Uanuku, the mangaia, who had run up Kei'â's main valley to save the two refugees who were relations of his mother's (Gill 1984 [1894]: 201-6). Major internal thoroughfares appear in other districts: Ivirua possessed te ara nui o Toi 'the main road of Toi' (Rakauruaiti and Aratangi n.d.). Despite the existence of such arterial paths, most interior tracks in the pre-Christian era were typically narrow, with people walking in single file (Fig. 7; Gill 1876a: 42-43; 1984 [1894]: 76-77, 146).

In selecting battlefields to decide the next mangaia titleholder, challenging leaders made sure that there was an internal pathway leading off the chosen site, allowing quick access either to the mountain or the makatea for the defeated party, as at the battle of Rangiue in Ivirua (Gill 1984 [1894]: 47; Reilly 2003: 38). These escape paths ensured that most battles were 


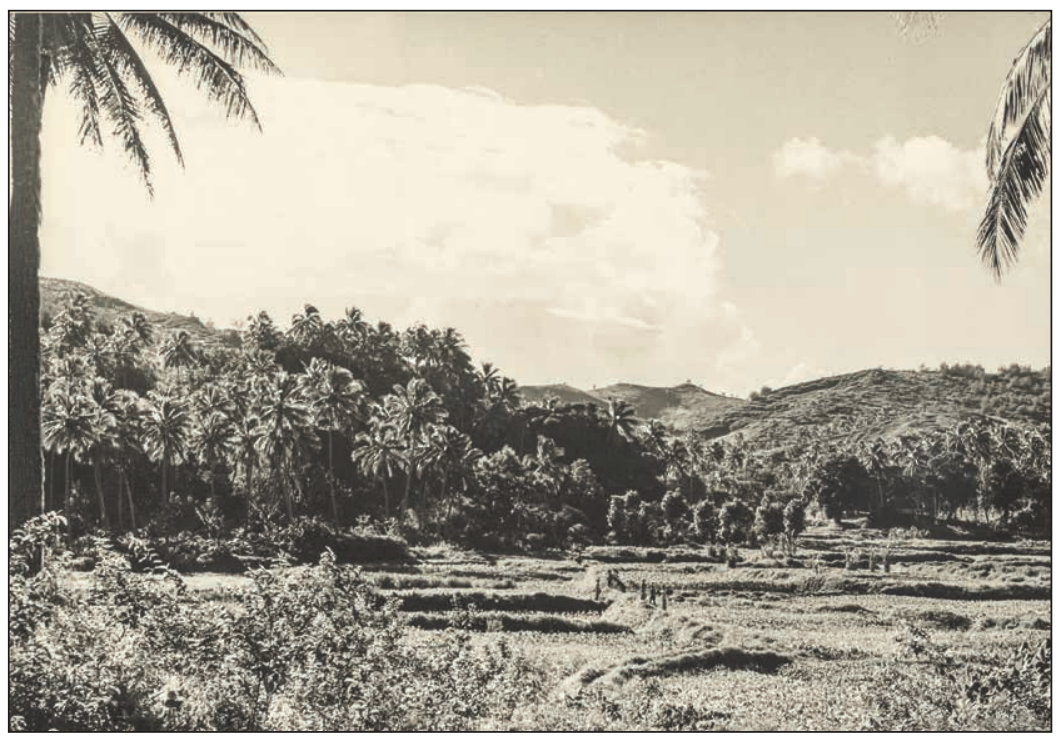

Figure 7. An old single-file path (centre) crossing the taro swamps in Kei'a's valley towards 'Aka'oro, c. 1950s. Photograph by Donald Marshall, courtesy of D.S. Marshall Archive, University of the South Pacific, Cook Islands Campus.

not decisive ones resulting in heavy casualties. An exception to this was the battle of Āua in Kei'ā where paths became an important factor in the destruction of the superior force under Rāei by those following Mautara. As Mautara's smaller force descended a narrow path from Veitātei into Kei'ā his secret supporters on Rāei's side realised Mautara's army could be easily bottled up on the track by a small group of warriors. One of these supporters signalled Mautara to lead his band by a more circuitous path, enabling them to emerge behind Rāei's assembling formation. This manoeuvre, along with a coordinated surprise attack from the secret supporters against their former companions, pushed the defenders into a confined space where there were no lines of escape along paths towards either the sea or interior (Gill 1984 [1894]: 211; Hiroa 1971 [1934]: 63; Reilly 2003: 65-67).

The numerous paths criss-crossing the valleys included many side roads or alternative tracks that were less travelled, because either they took a long way around or went through more challenging terrain. These backroads allowed for much surreptitious movement around the island. Refugees took them to escape detection by alert parties of enemy warriors (Gill 1984 [1894]: 
115-121, 155). Wives of such defeated refugees used them to bring food and support to their trapped partners (p. 291). In Mangaia, marriages being exogamous, these women often came from the victorious descent group and so could move about quite freely (Hiroa 1971 [1934]: 91). The fortunate Maikai, out collecting fallen chestnuts with other women, took such a path to elude pursuing enemy warriors ('Aerepō n.d.e; Gill 1984 [1894]: 287-89; Shibata 1999: 315,377). Such unfrequented paths were favoured by hunting parties tasked with surprising and killing the designated human sacrifice for a new mangaia's inauguration rituals (Gill 1876b: 302).

\section{JOURNEYS}

\section{Mourning the Dead}

When someone died or was killed in battle, immediate family carried them in a procession, sometimes for considerable distances, before interring them in the burial cave set aside for the deceased's descent group (Gill 1876b: 211-14). The mourning party would bring food for the dead and stay there for some days (pp. 187-89). For some time following a death, a mourning family would repeat the journey to the burial cave in order to reoil and reclothe the body (Gill 1876a: 75-76). To remember their loved one some families undertook exhausting processions around the island during which they would pause periodically to perform laments and appropriate funeral dances, before finally returning home (pp. 182-83, 187).

On the death of a prominent person, a manu 'messenger' ran around the island announcing the news at the border of each of the six districts. Following that announcement, extended family members would travel with gifts to the dead person's house. The young men of the deceased's district would go and fight in ritual battles, called 'e teina nō te puruki 'a younger brother of war', with each of the other districts. Following each battle, the opponents would join up and travel on to the next district, and so on, until the men from all the districts returned as a single group to the place where the body was laid out (Gill 1876b: 268-69).

When Kurapē'au's husband, the priestly medium 'Ākunukunu, was assassinated by her own kinsmen, after she had promised him her people's protection, she began wandering around on a protracted journey of mourning, up mountain ridges and through valleys in Ivirua and Tamarua districts. Her suffering only ended with her death at the hands of the refugee warrior, Tamangoru, at a place called Rū-ā'iva, the site of a marae for the Tepei (Teipe) clan $(k \bar{o} p \bar{u})$, probably near the foot of the mountain ridge at the end of the Vaiaua valley (Fig. 3). The killer hid her body in a nearby taro patch where it was discovered, eight days later, by her son, Mautara, following an extensive search throughout the area (Gill 1984 [1894]: 124, 128-29; Hiroa [1934] 1971: 175; Mautara n.d.). 
Kimi atu koe i tō metua

Tei uta $\bar{e}$, i te vao roa,

I te po'o $i$ Vaiaua.

You searched for your parent

(You found her) inland, in the long valley,

At the end of Vaiaua.

$\cdots$

Mangere i kona e,

Tei Rū-à 'iva è.

Left there,

At Rū-ā'iva.

\section{Rituals and Sacrifices}

The inauguration of a new mangaia involved a sequence of seven processions by large groups around the entire island. The first procession was the most violent, occurring as it did soon after the decisive battle to determine who ruled the land. The victorious army would march around the island to assert their authority, killing anyone foolish enough to cross their path. Later processions were marked by ritual acts at the island's marae, and included a ceremonial breaking of weapons, to mark the shift from war to peace. The final procession involved a beating of drums throughout the island, signalling the cessation of violence and the advent of peace (Gill 1876b: 294-305; Reilly 2009: 248-59).

Prior to the final procession, the presiding ariki 'high priest' nominated a victim and selected warriors to hunt for them and bring their body to the marae of 'Aka' oro in Kei'a (Fig. 3). These hunting parties might travel quite far, often by backroads at night to maintain secrecy, only to find victims being sheltered by protectors or in hiding, and requiring trickery to catch. Hunting parties were known to kill people connected to a victim who they happened to come across. When caught a victim was carried in a procession round parts of the island to 'Aka'oro. For example, the victim 'Akaruke, a young boy, was taken alive and led by a rope to various leading chiefs on the northern side of the island, visits attended by some ceremony. At the end of the sacrifice, portions of a victim's body were carried back to each of the island's marae (Gill 1876a: 36-42, 277, 344-6; 1876b: 297, 302-3, 306; 1885: 232-33; Reilly 2009: 257).

Periodically, the ariki pa $u t a$ 'inland high priest', assisted by the medium (pi 'a atua) for the important spirit power, Mōtoro, summoned the young people of each descent group to return to their tribal god's marae, located in the group's ancestral homeland. There they underwent a ritual recognition of their name, as a means of identifying to which spirit power members of the younger generation belonged (Gill 1876b: 38). 


\section{Killings and Theft}

The killing of people involved extensive and frequently clandestine movements across the landscape. The violence normally took place secretly during the darkest period of the lunar month between the 17th to 28th nights: Rākau, Rākau-roto, Rākau-'aka'oti, Korekore, Korekore-roto, Korekore'aka'oti, Tangaroa, Tangaroa-roto, Tangaroa-'aka'oti, 'O Tāne, Rongo-nui and Mauri (Gill 1876b: 318-19). The killers were proverbially likened to the unga puku 'ara 'coconut or robber crab' (Birgus latro), which also emerged on these nights and travelled long distances across the island in search of food (Gill 1876a: 277). As with sacrifice victims, killers seeking retribution might use trickery to lure their target into walking away from their protector's residence, across country, to a killing ground in an unpopulated spot, such as a mountain ridge (e.g., Gill 1885: 100-102). In other cases, a killing party would travel to the location of those targeted for retribution, often covering a considerable distance. Taipiro brought a Tonga 'iti war party from Tamarua, in the east, across the mountain, to a makatea cave located in Tava'enga, in the northwest (Gill 1984 [1894]: 83-85). A killing party set off from Ara'ata marae in Kei' $\bar{a}$, through the inland living areas in Tava'enga and Karanga districts where they slew several enemy leaders, and then across Ivirua's makatea to a seaward-facing fishers' cave, Ananui, where they attacked a large party of enemies (Fig. 3). Famously, this war party used calabash torches: just one to guide their journey, before lighting the rest to illuminate the cave attack (pp. 18-21; Reilly 2003: 30-33). Other killings were more opportunistic. A refugee hunting party came from Ivirua to Kei'ā's coastline in search of food and unsuccessfully tried to kill a fisherman on the reef, before eluding pursuing warriors in the makatea (Gill 1984 [1894]: 175-77).

When the Ngāti Vara mangaia, Te Uanuku, was assassinated at night in his home in Ivirua, the conspirators also tried to finish off his influential father, Mautara, living in Kei'ā. Warned of their approach he and his family escaped, heading first to pick up his son's body and hide it from any ill-treatment, probably at Nūkino, on the mountain ridge dividing Ivirua and Tamarua, before moving through Tamarua to Veitātei, recruiting additional supporters, until they encamped at Âriki near Lake Tiriara (Fig. 3; Gill 1984 [1894]: 209-10; Reilly 2003: 65; 2009: 224-27; Shibata 1999: 163).

Extended wars and natural calamities like drought affected the availability of food supplies, and prompted those affected by hunger to venture into more bountiful areas to steal food. Typically, they would creep across the island on the moonless night dedicated to 'Iro, the spirit patron of thieves, and take various foods, especially māmio 'taro' (Colocasia esculenta) but also other important crops, like banana. One Ivirua thief visiting Veitātei spotted a good target and returned on the appropriate night. Landowners ('atu 'епиа) moved about, especially on the thieving night, trying to safeguard their 
plantations. If a thief was identified, the afflicted landowners might travel en masse to the perpetrator's district and destroy all of its crops as a collective punishment, forcing the thief's family to kill him. Similarly, hungry war refugees who came down from the makatea and were caught taking food from inland plantations might be killed by vigilant landowners (Gill 1876a: 47-51; 1876b: 318; 1885: 65-66).

\section{Escapes}

Mangaians enjoyed telling Gill stirring stories of escape by their ancestors from certain death at the hands of enemy parties, often taking him to the stage set of their narrative to point out significant landmarks (e.g., Gill 1984 [1894]: 296-97). The following is a selection of such escape stories (for others see pp. 177-79, 287-89; Gill 1876a: 344-46). A lone survivor from a massacre of feast-goers at Tāpāti (Tāpātiu), in Kei'āa, ran off to warn priestly mediums at Tuopapa (Tuāopapa) in Tava'enga district and at Te Ruakeretonga in Karanga, before racing on to notify his own people in Ivirua who hid in the large Te Ana-o-kākāia refuge cave (Fig. 3; Aratangi n.d.c; Aratangi 1989; Gill 1984 [1894]: 166; Reilly 2003: 60; 2009: 211-14). ${ }^{7}$ The escapee, Matenga, made his way through Tamarua's makatea to the coast where he took a fishing boat and paddled around the length of the island to Kei ${ }^{\top} \bar{a}$, where his brother-in-law protected him (Gill 1984 [1894]: 292). Besieged with his supporters in the refuge cave behind Lake Tiriara, in Veitātei, Panako famously slipped through the enemy lines dressed and walking like a woman out collecting firewood. Unchallenged, he journeyed to and from Tamarua by an unfrequented backroad, successfully concluding an alliance with One and his Tonga'iti people to break the siege (pp. 76-79; Reilly, 2003: 41-43). Kie of Ngāti Tāne carried her seriously wounded husband, Atatoa, out of a fight at Okio, at the foot of the inner makatea cliff in Kei'ā. Still pursued by the enemy she carried him up a cliff path to Te Anaroa and then Te Anaiti caves: "Pikaio, e Kie, i tō tāne, / E 'apai atu i Te Anaroa, $i$ Te Anaiti" "Tenderly wrap up your husband, o Kie, / And carry (him) from Te Anaroa to Te Anaiti'. Fearing pursuit she then carried him by way of the makatea path, Te 'Akā'utu, to a cave of the same name lying at the foot of the makatea overlooking the sea where, despite her nursing, he succumbed to his wounds (Fig. 3; Gill 1984 [1894]: 296-304; Mataora Harry pers. comm., 18 October 2001; Tua'ine Papatua pers. comm., April 2001). ${ }^{8}$

Some escape stories highlight the vulnerability of less powerful groups in Mangaian society, particularly children and young people, during periods of sustained warfare associated with challenges for the mangaia title. For various reasons they became separated from other family and would move from shelter to shelter in remoter areas, foraging on local wild foods, ever fearful of capture by their enemies or of being killed by hungry refugee 
warriors. In these and other stories, Gill's consultants suggest that the killing of young people was considered socially and culturally abhorrent, and perhaps only occurred at times of widespread famine brought on by the disruptions to normal life caused by warfare (e.g., story of Tukekovi in Gill 1876a: 123-24). Two well-known stories illustrate the secretive journeys of such youthful escapees.

After the defeat of their descent group three young girls, Kaiara and her two younger sisters, hid in Te Mata-o-Rongo, an area of the makatea in the east of Mangaia, rather than accompanying most of their kin to the refuge cave of Te Ana-o-kākāia in Ivirua (Fig. 3). The women lived on wild foods and fruits, such as the nono 'Indian mulberry' (Morinda citrifolia), in the region of Poutoa on the borderlands of Ivirua and Tamarua (Fig. 3). A party of refugee warriors discovered them and captured the younger sisters who (according to Gill) were later killed and eaten. Kaiara escaped a determined pursuit, hiding in various small holes in the makatea, before making her way in the middle of the night into the makatea in Ivirua near the coastline. There she met up with Tavero, another kinswoman of about her age, and they lived in this area until they were caught by another hostile band. After escaping again back into the makatea, they left the Ivirua area and, after a difficult journey of some days through the interior of the rāei kere, reached Tamarua where they found a lifetime's protection with their cousin, Te Tui, and her husband, the ariki, Namu (Gill 1984 [1894]: 184-91).

Later on, the refugees hiding in Te Ana-o-kākāia panicked following news of their side's heavy losses at the battle of Puku-ō-to' $i$, in Tamarua, and fled in all directions (Fig. 3). The young brother and sister, Vaiā and Mangaia, made for Marotangi 'ia, in the makatea, possibly in Veitātei district. The siblings deliberately chose their new hiding place because it had plenty of wild foods to subsist on, including land crabs (tupa, Cardisoma carnifex), rats (kiore, Rattus exulans), fruit bats (moakirikiri, Pteropus tonganus), and even the occasional fish, cautiously caught from the reef, along with the berries, roots and herbs that grew in the makatea. Subsequently, Ngako, an escapee from Puku-ō-to'i, who had initially hidden in Tamarua's makatea, joined the siblings in their hideaway. Fearing that he might in desperation kill and eat them, Vaiā and Mangaia escaped and ran on to Kei'ā where they were eventually given protection from relations on the victorious side (Gill 1984 [1894]: 199-202). ${ }^{9}$

\section{Forced Migrations}

Individuals, families and groups might be forced to move, either elsewhere in Mangaia, or more seriously, out to sea. In a number of cases these people had unsuccessfully challenged the authority of the ruling mangaia title holder and his supporting chiefs. Such leaders had control of all the island's districts 
and sub-districts, including those of their opponents, all of whom came under their mana. Inevitably, locals from other descent groups tried to challenge that power. Less serious challenges resulted in internal displacements, as when Autea of Ngāti Tāne, a clan living in parts of Ivirua and Tava'enga, refused a request from his sub-district chief and was evicted, along with his family, from their lands and forced to seek refuge with his brothers in Tava'enga (Gill 1984 [1894]: 99-102). A mangaia title holder might expel a supporting chief and his followers who were found to be challenging the former's authority. As in the case of Arepe'e this could precipitate conflict (see Reilly 2009: 179-93). In more serious situations ruling chiefs would require unsuccessful challengers to sail into exile. When leaders from a descent group, unrelated to the ruling chiefs, were discovered plotting they and their families were forced to sail away from the island on ocean-going double-hulled $\mathrm{pa} i \bar{\imath}$. Some of them famously reached Rarotonga where they were allowed to settle (Gill 1984 [1894]: 130-36; Reilly 2003: 44-46; 2009: 197-200).

The people of a district might force someone to leave their lands. When Ue, from Tahiti, sought to introduce his spirit being and build it a new marae, Maungaroa, in Tamarua (Fig. 3), the locals, who worshipped another god, drove him out of their valley into the bleak rāei kere, after which Ue sailed away to Aitutaki with his lone local supporter (Gill 1984 [1894]: 58-59).

A young man might sail out to sea to escape a social death caused by personal humiliation. Before he set off family and friends would intervene, trying to dissuade the man from his action. Thus Paoa left after being berated by his father for his choice of marriage partner and told to leave the island. Paoa's wife, as well as senior kinsmen, pleaded with him, but without success. Various relations, including an ariki pa tai, even paddled after him still calling out to return, only to perish with him after being struck by a huge wave (Gill 1984 [1894]: 275-77).

\section{Seeking Refuge and Protection}

In the battles to control the mangaia title, those on the defeated side would seek to escape death by disappearing into the remote, bush-clad fastnesses of the upper valleys or the makatea, with the intention of later finding protection from relations connected with the other side, as happened with Te Vaki (Gill 1984 [1894]: 69-71, 129) and Namu (pp. 152-56, 158, 189). The story Gill heard sitting on a hilltop about Vivi is a good example as it shows how composers remembered in their songs many of the details of the landscape through which such refugees moved (see pp. 116-122 for the story and songs; see Fig. 8 for image of mountain Rangimōti ${ }^{\circ}$ a, and steep upper valleys). 


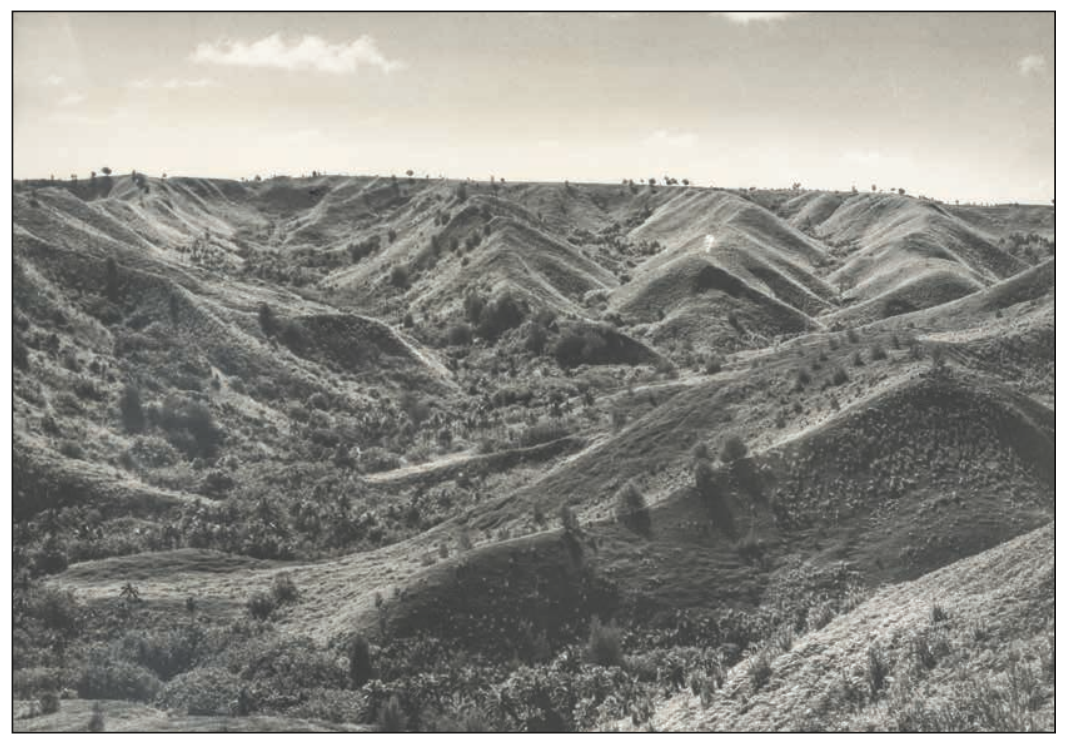

Figure 8. Valleys with Rangimōti‘a plateau in the background, c. 1950s. Photograph by Donald Marshall, courtesy of D.S. Marshall Archive, University of the South Pacific, Cook Islands Campus.

Originally, Vivi, along with his teina 'younger brother', Tito, lived with other Tepei tribal members in Ivirua, on the eastern end of the island, but they escaped their enemies by climbing up the makatea cliff at Tetuokura and taking refuge in the rāei kere on the borderlands of Veitātei and Kei' $\bar{a}$, in places like Motuvera cave, overlooking the sea.

Tikina i tai ē, tei Motuvera

Tērā roa tei rotopū i te rāei.

Tei Tetuokura, i kake ake nā Pei toe

I o pikimato, 'ānau atu i te kāinga.

Fetched from the sea, at Motuvera

Long there within the rāei.

At Tetuokura, the survivors of Pei climb up

The cliff face, (from their) natal homeland. 
Despite the remoteness of their refuge, its various localities are remembered in the songs. They allude to the brothers' various refuges and food-working places, either along the shore, like Avaavatakina, Avaavaotao, Ronaki and Putaranunga, or in the makatea, at Tuanaki and Tepikoiti.

Mautara sent a message to these kinsmen inviting them to come and live under his protection: " 'O 'ai te puta ia uta? / Mautara koi i te kiko o Tāne" 'Who invited (Vivi and Tito) to the interior? / Mautara, the flesh of Tāne'. Various songs praise Mautara's protective gesture: he is letting down a rope to the refugees dwelling in a bottomless pit ("Taura tukua è $i$ te tāeva é !"), or sheltering refugees in his house ("Te 'are 'ao nā Mautara"), a favourite Mangaian metaphor. To take up this offer Vivi and Tito wisely travelled at night, crossing the mountain down a ridge-line path and hiding in Takimivera, a secluded area of "impervious thickets", near Mautara's residence in the narrow Te Aumoko valley: " 'Eketia i raro i Teaumoko / Tei Takimivera 'oki te pūnanga / Pūnanga i te 'ao ê!" 'Climb down into Teaumoko / The refuge was at Takimivera / Refuge for the defeated!'

Mautara was the priestly medium for the powerful Ngāriki people (ivi), and in order to hear the voice of their god, and share in the food gifted to the medium, many of its leaders lived near his home. One of them, Tamangoru, suspected their medium was sheltering refugees and instituted an extensive search of the area. Realising their peril, Vivi and Tito tried to escape up the mountain (to the location where Gill heard their story).

Pūkiekie e kore rāi Tokoano ai

E oro ei Vivi e

Mei uta i te vao

Ta'i puku kakengatā, e kōrua.

Helpless were (the sons of) Tokoano (Vivi and Tito)

Vivi ran away

From the valley inland

You two (perished) on a hard-to-climb hill.

Vivi managed to get to the top only to find his escape blocked by the warriors Tamangoru and Koputureia. He threw himself back down the slope while his pursuers took a path through the mountain's tuānu 'e 'fern' (Dicranopteris linearis):

Kua taka 'aere, taka io Vivi nei,

Kua tangi te rau o te tuānu'e,

'O te vaevae 'oki o te tamaki,

Koputureia è Tamangoru. 
Falling, Vivi fell down,

The leaf of the tuannu'e sounded

(Under) the feet of the fighters,

Koputureia and Tamangoru.

They reached Vivi as he lay, barely conscious, on the ground in Te Auiti valley (Fig. 3), and killed him.

Pokia io i te kāivi i te kārava

'Ua 'amanga te rima o te tamaki

I uta $i$ Teauiti i te vao é!

Vivi e tueruia rā $\bar{e}$ !

Concealed on the crest of the ridge

Caught in the hand of war

Inland in the valley of Teauiti (he perished)

Vivi was hunted to death.

Meanwhile, Tito hid himself for a couple of days in a house amongst the thick bushes at a place called Te Tānga-a-te-uanuku, in Mangarua valley, before he too was discovered and slain.

'Ua kimikimi Ngāriki $\bar{e}$

Nā ivi ta ito ia Tito te vi para $\bar{e}$

Tei uta Tito i te vao mangarua

Pō rua 'oki au e pokia io.

Ngāriki hunted about

That ancient tribe for Tito the short-lived

Tito stayed inland in the Mangarua valley

For two nights I lay concealed.

Tei miri Tito i Tetānga-a-te-uanuku

Tō 'are rau na'e kopiopiotā

'Eia' 'a te 'ao i toe ai é!

Tito was (hiding) at the back of Tetānga-a-te-uanuku (Hunted in) your sheltering kingfern-leaved house (Tamangoru said,) Don't let the refugee survive!

For those refugees who managed to avoid their enemies, the next step required them to undergo a necessary ritual act before being reintegrated into the community. Their protectors would escort them around the island in a procession which ended with immersion in a sacred pool, probably Vairorongo, in Kei' $\bar{a}$ (Fig. 3), in order to mark their transition to a new life (Gill 1984 [1894]: 234). 


\section{Utilising Land and Sea Resources}

The elite of Mangaia made use of the land's bounty, maximising their access to such plenty by travelling about through different districts. When priestly mediums moved from district to district to perform various rituals at marae, their tribal leaders accompanied them in order to share in the large volume of food offerings given to the medium as a spirit being's human representative (Gill 1984 [1894]: 69, 117). Not for nothing were sub-district chiefs called kairanga nuku 'land-eaters', referring to their consumption of their land's produce (Hiroa 1971 [1934]: 124). To this end, the elite had multiple residences scattered around the various districts; for example, the Te 'A'aki clan leader, Iro, lived in his ancestral home, Tamarua, and in Rupetau, Kei'ā (Fig. 3), while other Tonga 'iti $i v i$ leaders spread themselves across Tamarua, Veitātei and Kei‘āa (e.g., Reilly 2009: 138, 186, 199).

Many resources of the land and sea were available to everyone. People would travel from different parts of the island in order to access them. A good example are the different rocks used for tools or in tool making. Basalt was taken from quarries at Rupetau, in Kei'ā, and at the head of Matā'are valley, located near the centre of the island where the boundaries of Tava'enga, Kei' $\bar{a}$, Veitātei and Karanga converge (Fig. 3; Gill 1876a: 117; Shibata 1999: 132). Red quartz, used to chip the basalt into shape for toki 'adzes', came from a quarry at Ma'ana, located to the northeast, in Karanga district (Gill 1984 [1894]: 223-24). The stalagmites and stalactites found in the makatea caves, especially in the räei kere, the area of makatea on the south and southeast coast, provided the stone from which craft specialists (ta'unga) produced reru 'food pounders' (p. 228; Kirch 2017b: 213-14).

Individuals or groups of men or women regularly walked by way of the makatea paths to go fishing by day, and torch-fishing by night, on the reef, or in small boats just off it, seeking to catch the many varieties of fish living in the reef's extensive underwater fissures. Sometimes, large crowds would race down from their inland residences if abundant fish were spotted (Gill 1876a: 36, 131, 137, 145, 278-80, 284-91, 307; 1885: 67; 1984 [1894]: 203-4, 247, 276, 279; Hiroa 1971 [1934]: 68; Shibata 1999: 229). Women went night fishing inland at Lake Tiriara, in Veitātei (Fig. 3), for kōura vai 'fresh-water shrimp' (Macrobrachium sp.) and kōkopu 'fresh-water brown gudgeon' (Eleotris sp.) (Gill 1984 [1894]: 177; Shibata 1999: 101, 107). Men hunted for the tupa crab which lived in burrows in the sandy, coastal areas and in inland soils (Buse with Taringa 1995: 525; Gill 1876a: 136; Shibata 1999: 224; Whistler 2009: 193-94). Girls and single young women carried calabashes to the sea to fetch salt water for cooking and to inland fresh-water springs for drinking water (Aratangi n.d.d; Gill 1984 [1894]: 104). Everyone resorted to the interior streams and ponds for bathing, even refugees in hiding, especially after being out at sea (e.g., p. 180; Hiroa 1971 [1934]: 68; Reilly 2015: 153-54, 156). 
People visited the wild bush of the makatea, from their inland residences, for a number of food and plant resources (Fig. 9). Youths and men hunted at night for the abundant kiore, a popular food valued for its very sweet-tasting meat (Gill 1876a: 15, 317, 328; 1984 [1894]: 124-25; Williams 1837: 210). Men hunted various birds, such as the easily caught $t \bar{t} t \bar{l}$, tentatively identified as the black-winged petrel (Pterodroma nigripennis) (Buse with Taringa 1995: 499; Clerk 1981: 259; Gill 1876a: 135; 1984 [1894]: 26), and the ngoìo 'brown noddy' (Anous stolidus), which was sometimes caught and kept as pets (Clerk 1981: 258-59; Holyoak 1980: 33; Shibata 1999: 173). ${ }^{10}$ Besides being a food source, such birds also provided ta 'unga with feathers for clothing and decorations: the red tail feathers of the tavake 'red-tailed tropicbird' (Phaethon rubricauda) were particularly desired (Gill 1984 [1894]: 228). Groups of women visited the makatea to pick up the ripe fallen nuts of the tuitui 'candlenut tree' (Aleurites moluccana), growing abundantly there, which they used as a lighting source, a sooty black dye and a famine food (Gill 1885: 192-93; 1984 [1894]: 152; Hiroa 1971 [1934]: 126; Whistler 2009: 30-31). Individual women came to strip the bark off the abundantly growing aoa 'Polynesian banyan' (Ficus prolixa) and make it into a coarse tapa cloth (Gill 1984 [1894]: 90). Ta 'unga visited Tava'enga's makatea to strip off the bark from the orong $\bar{a}$ 'nettle tree' (Pipturus argenteus) in order to manufacture a very strong fibre, particularly favoured for creating fishing nets and as backing for feather-decorated tīputa 'poncho-like cloaks' (pp. 26-28; Whistler 2009: 174-75). Young people came to the makatea to pick berries and flowers to make into 'ei 'necklaces', such as poepoe 'Job's tears' (Coix lacryma-jobi), poro 'iti 'red-berry nightshade, cannibal cherry' (Solanum viride) and the fragrant white Cape Jessamine flower, Gardenia jasminoides (Gill 1984 [1894]: 125; Shibata 1999: 220; Whistler 2009: 76; Wikipedia contributors 2017).

People collected various plant resources from around the island, such as wild foods, especially when other food sources were scarce. Low-status girls or women collected the bitter-tasting poro 'black nightshade' (Solanum americanum) and ' $a$ ' $a$ 'leaf-stalk of mämio', which could be cooked and eaten as a meal (Gill 1885: 232). People went inland and dug up the roots of the tuānu' $e$ fern from the interior hills and ridges (Allen 1969: 26; Gill 1876a: 149; Shibata 1999: 340). Women or young girls, in groups or as individuals, would collect the fallen nuts of the $i$ ' $i$ 'chestnut' (Inocarpus fagifer or Inocarpus edulis), found in groves near streams in the interior, which were stored to provide a handy food source in the leaner winter months (Gill 1885: 194-98; 1984 [1894]: 111, 202, 286; Whistler 2009: 134-37). Groups, such as refugees, would pick the vi kavakava 'Otaheite apple or Polynesian plum' (Spondias dulcis) as a supplementary food (Gill 1984 [1894]: 231; Shibata 1999: 388; Whistler 2009: 195). ${ }^{11}$ The importance of the 'akari 'coconut' (Cocos nucifera) as food and raw material meant that even refugees had to 


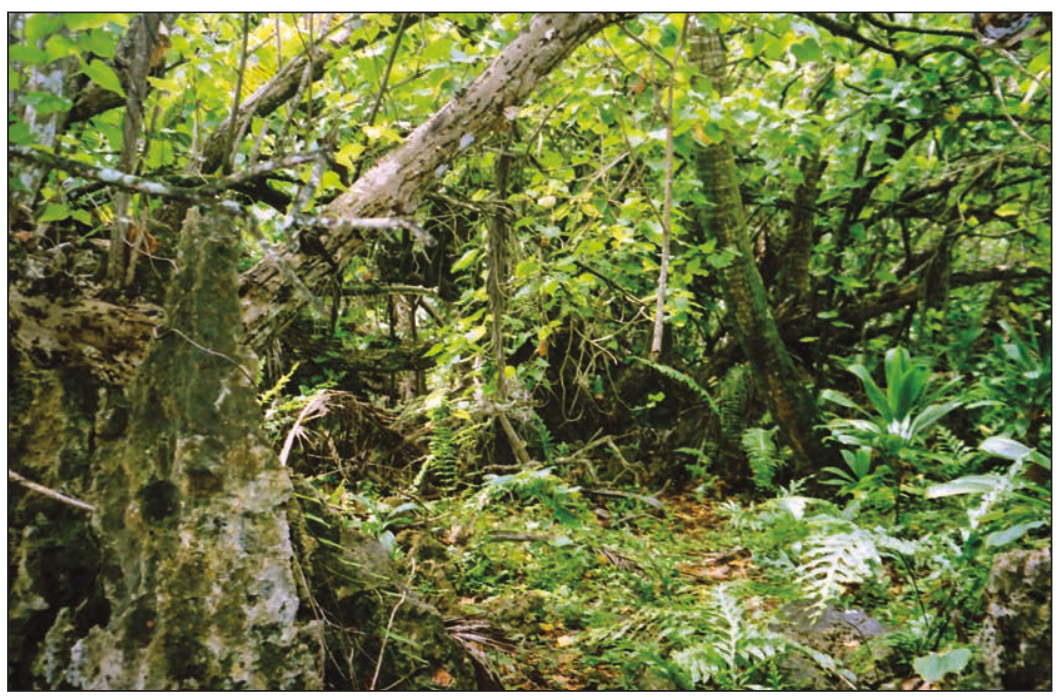

Figure 9. The wild bush of the makatea, on a track behind Lake Tiriara, Veitātei. Author's photograph, 2001.

risk discovery and venture out into the valleys and coastal areas to access them (Gill 1984 [1894]: 196; Hiroa 1971 [1934]: 62). ${ }^{12}$ Large building projects, such as a canoe, required groups to travel into the upper valleys to cut down trees from the stands of forest located there (Gill 1984 [1894]: 245).

\section{Entertainments}

During periods of peace, Mangaians would travel across the island to attend a range of festivals and other events involving the performing arts, particularly dance, and sports. The performing-arts events, known as kapa, and involving numerous dance-songs and a large feast, occurred during the nights of ' $\mathrm{O}$ Tāne and Rongo-nui, named for the two principal spirit patrons of dance (Gill 1876b: 219 fn. 1, 318). Specific dances came under the patronage of young and good-looking spirit beings known as tapairu, believed to travel from 'Avaiki 'Spirit World' to participate in these performances (pp. 256-62). These kapa could be huge events and lasted all night: one comprised some 200 male dancers, with most of the island's population travelling to watch the performances (Gill 1984 [1894]: 251-52). Another night-time event, the tara kakai 'death recital', commemorated the recent death of a person of rank. Members of their descent group would attend and perform as many as 60 
specially composed laments while the organiser liberally provided participants with food (Gill 1876b: 269-71; Hiroa 1971 [1934]: 192).

Feasts were another significant entertainment event to which people might be invited from other parts of the island. Some involved the whole island community, with one half of the island inviting the other. Invitations to such events were communicated by a youthful messenger, the manu or 'oro 'oro, who ran around the island silently tying an 'uku kikkau 'tail end of coconut frond' to the residence of each invitee of rank, implicitly inviting all of their subordinate people as well (Buse with Taringa 1995: 293; Gill 1876a: 134; 1885: 204-5; 1984 [1894]: 214; Shibata 1999: 185, 363). While the hosts accumulated large stocks of food for several months, those invited would manufacture tapa cloth as a return gift. On the appointed day the guests would travel across the mountain paths down into the valleys carrying their load of gifts and return with their share of the food (Gill 1876a: 132, 1885: 102). ${ }^{13}$

Major artistic and sporting festivals attracted large crowds who would travel from around the island to attend. These events included daytime teka 'dart' throwing games during which dance-dramas would also be performed. These activities were organised and performed by one sex for the other: when women put on a festival, the men would be invited to attend as spectators (Gill 1876b: 228, 243-44; Hiroa 1971 [1934]: 151; Reilly 2015: 156-57). Deaths of prominent persons might be commemorated by a daytime performance of the 'eva, a funereal event comprising various dramatically performed laments involving family and other mourners. For one 'eva Gill reported that most of Mangaia's population attended, all of them participating in the performance (Gill 1876b: 271-73).

$$
* * *
$$

Mangaia's people were in constant movement across the face of their island, utilising the complex of pathways radiating outwards from their valley homelands, to reach across the makatea to the sea, and over the mountain to other communities and resources located elsewhere in the island's natural landscape. They moved through a familiar country where every spot, even in the remotest makatea, could be recalled by name in the oral traditions repeatedly told down the generations about particular ancestors: the house sites they lived on; the paths they took to sea and mountain; the spots on the reef where they fished or fetched seawater; the ponds they used to wash in or drink from; the marae they processed to and worshipped at; the taro patches they cultivated; the natural resources they utilised; the spaces they feasted, danced and played on; the battlefields they fought upon; the refuges they fled to; and, the burial caves where their remains were deposited and mourned over. 
As the ancestors moved about the land they located themselves in specific spaces, conscious that they lived between the sea and the land, always facing towards the mountain, as the source of their life-sustaining fresh waters, their backs to the extensive wilderness of the makatea and the sea beyond. Their movements around the island, from one district to another, resembled the ancient sea journeys of their ancestors, as they voyaged west or east between islands. That sea orientation continued even after generations of life on Mangaia, the land itself imagined as a fish located within the larger ocean.

When Gill arrived to minister to his Christian parishioners he discovered this ancestral landscape by travelling on the ancient pathways, observing the distinctive nature of the landscape around him and hearing from his guides the traditions associated with the places he was visiting. He sought to remember the journeys and oral histories in writing, providing readers today with a window into this living world of the ancestors. When I started studying Mangaia's historical records my thesis supervisor, Niel Gunson, told me to get to know the island and the people by living in the field for a while. That way I would have a better insight into the written texts. It has taken me rather longer to understand what he was getting at. I think Chris Ballard's Oceanic historicities, with its privileging of landscape and those people who dwell within it, gets close to it (Ballard 2014: 105-7).

Some Mangaians, like Mataora, who took the time to teach me a little of what they knew about their island are no longer here to share their knowledge. Mataora lies buried alongside other kavana in the cemetery of his church in Oneroa. The landscape too has changed at least a little since we talked. There are new structures, like Vairorongo's water-pumping station, built to enhance the lives of Mangaians. Every generation reshapes their environment. They will have their own stories to tell about how past generations made their mark upon the land. Peter Gow (1995: 60-61) warns against reducing history simply "to one aspect of human material-making, the production of texts, representations". Instead, he argues that there are "other possible histories inside nature", including ones about vegetation, paths, old gardens and "telling stories in a particular place and at a particular time". Such "other histories", he suggests, should be thought of "as modes of lived experience". Mangaia's past will always remain alive in the landmarks and memories of the people whose place this is. As Gill understood, the stories the people of the land remember are the substance from which any island history is produced. 


\section{ACKNOWLEDGEMENTS}

This paper is based on historical research undertaken for a project on the cultural landscape of Kei'ā with Richard Walter and the late Mataora Harry between 2001 and 2003. Over the years Mataora patiently asked after our work, and I hope this belated paper helps repay the enormous debt Richard and I owe him for all his assistance over the years. The Mangaian cultural landscape map (Fig. 3) is based on field maps drawn by a research associate, James Robinson, along with data from maps in Allen (1969), Bellwood (1978), Buck (1993), Marshall (1927) and Land Information New Zealand (2014). The maps used in this article were kindly drawn by Les O'Neill, Department of Anthropology and Archaeology, University of Otago. Particular thanks to the former Cook Islands National Archivist, George Paniani, who kindly granted me access to the Mangaian kōrero 'oral history' series papers; Rod Dixon, University of the South Pacific, Cook Islands Campus, for permission to reproduce Donald Marshall's photographs; and Erica Newman, who digitised my old Mangaian photographs. Thanks also to the late Teariki No'oroa who first introduced me to orientations in Mangaia's landscape, and to Tua 'ine Papatua who shared some of his knowledge about the landscape and, along with his wife Liz, provided generous island hospitality to Richard and me during our field work. Finally, a particular thanks to the two anonymous referees whose feedback substantially enhanced this paper, and to the patience and helpfulness of the editor. Any remaining errors are my own and I welcome any corrections regarding the paper's cultural knowledge.

\section{NOTES}

1. Previously, Pāpā Aratangi, the Mangaian scholar whom I had known since 1987, had recommended Mataora as someone who could assist with my historical research. Thanks to a University of Otago research grant I was able to bring Mataora to Dunedin to work with me for several months in 1997. My 1998 visit was a continuation of this collaboration.

2. Note that Mangaian language texts often replace ' $k$ ' with a glottal stop, thus $k i$ uta or ' $i$ uta. Both forms appear in this paper.

3. Older Mangaian texts sometimes replace runga with the variant nunga (Shibata 1999: 163).

4. The variant ' $u k u$ appears to be a Mangaian term while 'iku is Rarotongan Māori (Shibata 1999: 363).

5. The variant miri is the Mangaian term while muri is Rarotongan Māori (Shibata 1999: 142).

6. In Mangaia, taro refers to the wetland plot while māmio is the local term for the Colocasia esculenta which grows there.

7. According to Mataora Harry (pers. comm., 24 October 2001), Te Ruakeretonga was a boundary stone (kena), suggesting this placename was located on a district or sub-district border.

8. Mataora Harry was a direct descendant of Atatoa. 
9. See Gill (1984 [1894]: 125-27) for a similar story involving two youths, Oromanarangi and Oromananuku.

10. Other birds that were hunted included the kau ' $\bar{a}$, tentatively identified as the longtailed cuckoo (Urodynamys taitensis) or the bristle-thighed curlew (Numenius tahitiensis), the tavake 'red-tailed tropicbird' (Phaethon rubricauda) and the pirake 'white-tailed tropicbird' (Phaethon lepturus) (Clerk 1981: 259-60, 266-68; Holyoak 1980: 16-17, 28-29, 35-36).

11. Gill calls the $v \bar{\imath}$ kavakava the "Brazilian plum-tree".

12. On uses of 'akari, also see Gill (1885: 204-66) and Whistler (2009: 60-75).

13. On feasts generally see Gill (1984 [1894]: 160-65, 214-16) and Hiroa (1971 [1934]: 138-41).

\section{REFERENCES}

'Aerepō, I., n.d.a. 'E Tua teia ia Rori. Ministry of Society Services, Cultural Development Division, Mangaian Körero Series. National Archives of the Cook Islands, Rarotonga.

n.d.b. 'E Tua teia nō 'Oimara. Ministry of Society Services, Cultural Development Division, Mangaian Körero Series. National Archives of the Cook Islands, Rarotonga.

—n.d.c. 'E Tua teia ia Rongoinga. Ministry of Society Services, Cultural Development Division, Mangaian Körero Series. National Archives of the Cook Islands, Rarotonga.

—n.d.d. Te Tua ia Mokea. Ministry of Society Services, Cultural Development Division, Mangaian Kōrero Series. National Archives of the Cook Islands, Rarotonga.

n.d.e. Te Tua ia Maikai. Ministry of Society Services, Cultural Development Division, Mangaian Kórero Series. National Archives of the Cook Islands, Rarotonga.

Allen, Bryant James, 1969. The Development of Commercial Agriculture on Mangaia: Social and Economic Change in a Polynesian Community. Unpublished MA thesis, Massey University, Palmerston North, New Zealand.

Aratangi, Pāpā, 1989. Letter to author, 21 March.

Aratangi, Tere'ēvangeria, n.d.a. Mate'anga o Uakoe. Ministry of Society Services, Cultural Development Division, Mangaian Kōrero Series. National Archives of the Cook Islands, Rarotonga.

n.d.b. Te Tua ia Varimangō. Ministry of Society Services, Cultural Development Division, Mangaian Körero Series. National Archives of the Cook Islands, Rarotonga.

n.d.c. Te Puruki'anga i rotopū i a Te Uanuku ē 'Akatara. Ministry of Society Services, Cultural Development Division, Mangaian Kōrero Series. National Archives of the Cook Islands, Rarotonga.

n.d.d. Te Puna Kei`ā. Ministry of Society Services, Cultural Development Division, Mangaian Kōrero Series. National Archives of the Cook Islands, Rarotonga.

Ballard, Chris, 2014. Oceanic historicities. The Contemporary Pacific 26 (1): 96-124. 
Bellwood, Peter, 1978. Archaeological Research in the Cook Islands. Pacific Anthropological Records No. 37. Honolulu: Department of Anthropology, Bernice P. Bishop Museum.

Bennardo, Giovanni, 2014. Space and culture: Giving directions in Tonga. Ethos 42 (3): 253-76.

Buck, Peter Henry (Te Rangi Hiroa), 1993. Mangaia and the Mission. Edited with an introduction by R. Dixon and T. Parima. Suva: Institute of Pacific Studies, University of the South Pacific in association with Bernice P. Bishop Museum.

Buse, Jasper with Rautati Taringa, 1995. Cook Islands Maori Dictionary. Edited by B. Biggs and R. Moeka'a. Rarotonga: Ministry of Education, Government of the Cook Islands.

Clerk, Christian, 1981. The Animal World of the Mangaians. Unpublished PhD thesis, University College, London.

Donaldson, Emily C., 2018. Place, destabilized: Ambivalent heritage, community and colonialism in the Marquesas Islands. Oceania 88 (1). Published ahead of print, 5 February 2018, using page numbers 1-21. DOI: 10.1002/ocea.5182

Gill, William Wyatt, 1876a. Life in the Southern Isles. London: Religious Tract Society.

1876b. Myths and Songs from the South Pacific. London: Henry S. King. 1885. Jottings from the Pacific. London: Religious Tract Society. 1984 [1894]. From Darkness to Light in Polynesia. London: Religious Tract Society; reprint ed., Suva: Institute of Pacific Studies, University of the South Pacific.

Gow, Peter, 1995. Land, people, and paper in Western Amazonia. In E. Hirsch and M. O'Hanlon (eds), The Anthropology of Landscape: Perspectives on Place and Space. Oxford: Clarendon Press, pp. 43-62.

Hau'ofa, Epeli, 2008. We Are the Ocean: Selected Works. Honolulu: University of Hawai'i Press.

Hiroa, Te Rangi (P.H. Buck), 1971 [1934]. Mangaian Society. Bernice P. Bishop Museum Bulletin 122. Honolulu; reprint ed., New York: Kraus.

Holyoak, D.T., 1980. Guide to Cook Islands Birds. Rarotonga: Cook Islands Library and Museum Society.

Ingold, Tim, 1993. The temporality of the landscape. World Archaeology 25 (2): 152-74.

Kirch, Patrick Vinton, 1994. The Wet and the Dry: Irrigation and Agricultural Intensification in Polynesia. Chicago: University of Chicago Press.

-1996. Late Holocene human-induced modifications to a central Polynesian island ecosystem. Proceedings of the National Academy of Sciences USA 93: 5296-5300.

2017a. The Mangaia socio-ecosystem: Environmental and ethnohistoric perspectives. In P.V. Kirch (ed.), Tangatatau Rockshelter: The Evolution of an Eastern Polynesian Socio-Ecosystem. Los Angeles: Cotsen Institute of Archaeology Press, pp. 9-29.

2017b. Material culture and technological change at Tangatatau Rockshelter. In P.V. Kirch (ed.), Tangatatau Rockshelter: The Evolution of an Eastern Polynesian Socio-Ecosystem. Los Angeles: Cotsen Institute of Archaeology Press, pp. 175-218. 
Kirch, Patrick Vinton (ed.), 2017. Tangatatau Rockshelter: The Evolution of an Eastern Polynesian Socio-Ecosystem. Los Angeles: Cotsen Institute of Archaeology Press. Kirch, P.V., J.R. Flenley and D.W. Steadman, 1991. A radiocarbon chronology for human-induced environmental change on Mangaia, Southern Cook Islands, Polynesia. Radiocarbon 33 (3): 317-28.

Kirch, Patrick Vinton and Terry L. Hunt (eds), 1997. Historical Ecology in the Pacific Islands: Prehistoric Environmental and Landscape Change. New Haven: Yale University Press.

Kirch, Patrick Vinton, David W. Steadman, Virginia L. Butler, Jon Hather and Marshall I. Weisler, 1995. Prehistory and human ecology in Eastern Polynesia: Excavations at Tangatatau Rockshelter, Mangaia, Cook Islands. Archaeology in Oceania 30 (2): 47-65.

Land Information New Zealand, 2014. PiTopo25-PI17 Mangaia. Available at: http:// topo.linz.govt.nz/pacific_islands/tiff/PI17_TIFFv1-00.tif

Lepofsky, Dana, Chelsey Geralda Armstrong, Spencer Greening, Julia Jackley, Jennifer Carpenter, Brenda Guernsey, Darcy Mathews and Nancy J. Turner, 2017. Historical ecology of cultural keystone places of the Northwest Coast. American Anthropologist 119 (3): 448-63.

Mark, Mary V., 1976. The Relationship between Ecology and Myth in Mangaia. Unpublished MA thesis, University of Otago, Dunedin.

Marshall, P., 1927. Geology of Mangaia. Bernice P. Bishop Museum Bulletin 36. Honolulu.

Mauriaiti, T., R. Koroa, I. Papatua, L.N. Marii, P. Aratangi, T. Aratangi, T.U. Mautairi, M. Dean, Te V. Rere, V. Tangatataia, M. Tangatakino, M. Dodson and I. Dodson (eds), 2006. Reo Mangaia i te Reo Papa' $\bar{a}$ Puka 'Āite 'anga Tara: Mangaia Dialect to English Dictionary and English to Mangaia Dialect Vocabulary. Mangaia: [The Editors].

Mautara, n.d. Taunga Kiri o Kurapē‘au. Special Collections, Auckland Libraries. Grey New Zealand Manuscripts 45.

Mawyer, Alexander, 2014. Oriented and disoriented space in the Gambier, French Polynesia. Ethos 42 (3): 277-301.

Mawyer, Alexander and Richard Feinberg, 2014. Senses of space: Multiplying models of spatial cognition in Oceania. Ethos 42 (3): 243-52.

Myers, Fred, 2017. Shortcuts: Rant or reason: Old wine and new bottles in anthropology. HAU: Journal of Ethnographic Theory 7 (3): 8-12.

Oliver, Douglas L., 1974. Ancient Tahitian Society. Vol. 2: Social Relations. Honolulu: The University Press of Hawaii.

Rakauruaiti, Ravengenge and Tere'ēvangeria Aratangi, n.d. Te Tua ia Panako Tu'anga Mua. Ministry of Society Services, Cultural Development Division, Mangaian Körero Series. National Archives of the Cook Islands, Rarotonga.

Reilly, Michael, 2003. War and Succession in Mangaia from Mamae's Texts. Memoir No. 52. Auckland: The Polynesian Society. 2009. Ancestral Voices from Mangaia: A History of the Ancient Gods and Chiefs. Memoir No. 54. Auckland: The Polynesian Society. 
2010. Rediscovering the hidden heritage from Ancient Mangaia. In B. Hokowhitu, N. Kermoal, C. Anderson, M. Reilly, A. Petersen, I. Altamirano-Jiménez and Poia Rewi (eds), Indigenous Identity and Resistance: Researching the Diversity of Knowledge. Dunedin: Otago University Press, pp. 125-35.

2015. Ngaru: A culture hero of Mangaia. Journal of the Polynesian Society 124 (2): $147-87$.

Richards, Janet E., 1999. Conceptual landscapes in the Egyptian Nile Valley. In W. Ashmore and A.B. Knapp (eds), Archaeologies of Landscape: Contemporary Perspectives. Malden, MA: Blackwell Publishers, pp. 83-100.

Sauer, Carl, 1963. The morphology of landscape. In J. Leighly (ed.), Land and Life: A Selection from the Writings of Carl Ortwin Sauer. Berkeley, CA: University of California Press, pp. 315-50.

Shibata, Norio, 1999. Mangaian-English Dictionary. Rarotonga: The Cook Islands Library and Museum Society.

Whistler, W. Arthur, 2009. Plants of the Canoe People: An Ethnobotanical Voyage through Polynesia. Lawai, Kaua'i, Hawai'i: National Tropical Botanical Garden.

Wikipedia contributors, 2017. Gardenia Jasminoides. Wikipedia, The Free Encyclopedia, 7 Jan. 2017. Available online at https://en.wikipedia.org/w/index. php?title $=$ Gardenia jasminoides\&oldid $=758859379$

Williams, John, 1837. A Narrative of Missionary Enterprises in the South-Sea Islands. London: John Snow.

\begin{abstract}
A cultural landscape is pregnant with memories of the past that are remembered and retold through oral traditions. These memories include the movements of the ancestors through their natural world: how they orientated themselves within their landscape, the paths they took to travel from one place to another and the many kinds of journeys they embarked upon, such as ritual and mourning processions, expeditions to war, escapes to refuges, trips to access natural resources or jaunts to enjoy entertainments. This paper explores these movements as they are remembered within the cultural landscape of Mangaia in the Cook Islands.
\end{abstract}

Keywords: landscape, movement, Mangaia, directions, pathways, journeys

\title{
CITATION AND AUTHOR CONTACT DETAILS
}

Reilly, ${ }^{1}$ Michael, 2018. Moving through the ancient cultural landscape of Mangaia (Cook Islands). Journal of the Polynesian Society 127 (3): 325-357. DOI: http://dx.doi. org/10.15286/jps.127.3.325-357

${ }^{1}$ Correspondence: Te Tumu, School of Māori, Pacific and Indigenous Studies, University of Otago, P.O. Box 56, Dunedin 9054, New Zealand. Email: michael. reilly@otago.ac.nz 